\title{
Macroarray Detection of Plant RNA Viruses Using Randomly Primed and Amplified Complementary DNAs from Infected Plants
}

\author{
Bright Agindotan and Keith L. Perry
}

Department of Plant Pathology, 334 Plant Science Building, Cornell University, Ithaca, NY 14853.

Accepted for publication 4 August 2006.

\begin{abstract}
Agindotan, B., and Perry, K. L. 2007. Macroarray detection of plant RNA viruses using randomly primed and amplified complementary DNAs from infected plants. Phytopathology 97:119-127.

Membrane-based macroarrays provide a relatively inexpensive technology with the potential to detect hundreds of pathogens in a single assay. For the simultaneous detection of a large number of pathogens, it is necessary to obtain sufficient nucleic acids for labeling, and any amplification reactions need to be performed using unbiased, pathogen-nonspecific primers. A nonradioactive macroarray system is described to test for plant RNA viruses using 70-mer oligonucleotide probes immobilized on nylon membranes. Starting with a total plant RNA extract, comple-

anchor primer alone resulted in a relatively unbiased amplification of plant and viral RNAs. These cDNAs were chemically labeled and the product used as a target in hybridization analyses. The system was validated using RNA extracts from plants infected with Cucumber mosaic virus, Potato virus $Y$, and Potato leaf roll virus (PLRV). Despite the relative excess of host-derived nonviral sequences, viral RNAs were amplified between 100- and 1,000-fold and were detected in single and mixed infections. The macroarray sensitivity was comparable to that of double-antibody sandwich enzyme-linked immunosorbent assay, with PLRV being detected in sap dilutions of $1: 100$. The potential for the development of a relatively inexpensive multipathogen detection system is discussed.
\end{abstract} mentary DNA (cDNA) and second-strand syntheses were carried out using an anchor primer sequence with random pentamers coupled at the $3^{\prime}$ end. Subsequent synthesis by polymerase chain reaction using the
Additional keywords: anchor primers.
The most common methods of plant virus detection are variations on the enzyme-linked immunosorbent assay (ELISA) and the polymerase chain reaction (PCR) $(30,52)$. As a serological technique, ELISA with polyclonal antibodies has the advantage of being robust and detecting most strains of a given virus. The major drawback is that antisera for the detection of each virus of interest must be both available and affordable. PCR-based methods have the advantage of being both extraordinarily sensitive and requiring reagents that are easily accessible and relatively inexpensive. The downside of PCR-based methods is that, in order to be reliable, the $3^{\prime}$ ends of the oligonucleotide primers employed must be conserved among all strains of the virus. In most cases, with both types of methods, tests are performed for each pathogen individually. This may not be limiting for regional crop certification programs, where tests screen for only a small number of pathogens (e.g., with potato in North America) (45). In such cases, a collection of specific antisera would allow for ELISA testing, or a few different multiplex PCR assays might suffice. The problem becomes considerably more challenging when monitoring the international movement of seed or vegetative planting stock (e.g., grapevine, citrus, strawberry, or potato). In these cases, all known pathogens must be considered and the amassing of reagents becomes a limiting factor, because of cost and logistics.

The most promising technology for the development of multipathogen detection systems has been the advent of microarrays. Thousands of diagnostic nucleic acid 'probes' can be spotted onto a platform (glass slide) and hybridized with labeled 'targets' (i.e., nucleic acids extracted from specimens and chemically modified

Corresponding author: K. L. Perry; E-mail address: KLP3@ cornell.edu

DOI: 10.1094/PHYTO-97-0119

(c) 2007 The American Phytopathological Society with a fluorescent or other reporter) (6). A number of microarrays were developed for the detection and typing of animal viruses $(9,21-23,42)$. One of the first and most powerful of these arrays contained 70-mer oligonucleotide probes for the detection of 140 viruses and was employed to detect multiple viruses in human respiratory specimens without the use of sequence-specific primers (49). More recent versions of this 'pan-viral array' include oligonucleotides specific to more than 1,000 viruses, including those from plants (50).

Microarrays for the detection of plant viruses have been much more limited in scope and have employed relatively small numbers of probes $(1,5,7,8,24)$. Perhaps greater potential has been realized in the detection of other plant pathogens using membrane-based, 'reverse dot-blot' hybridization assays (20). These assays employed synthetic oligonucleotides and, when spotted at high densities as macroarrays, they approach the power of microarrays. This potential is well illustrated in the work of Levesque and colleagues in the detection of fungal, bacterial, and oomycete plant pathogens $(15,25,27)$. The identification of these pathogens has depended largely on the primer-specific amplification of ribosomal DNA sequences, an approach not applicable to the detection of viral pathogens. For viruses, multiplex PCR has been used to amplify several viral nucleic acids prior to hybridization (26, 28 ). The constraints to this process are the need to design primers for each virus and the optimization process involved in multiplex PCR. This method is not suitable for the detection of unknown virus nucleic acid sequences. Group- and genera-specific primers also have been used for the amplification of viral sequences (10, $13,16,17,37,38,41)$; however, there are many groups of viruses for which no effective generic primers are available. Thus, there is a significant need for the application of amplification methods that are relatively sequence independent.

This report demonstrates the use of sequence-nonspecific amplified complementary DNAs (cDNAs) as substrates for labeling and 
the detection of plant RNA viruses. Of greater significance is that these approaches can be combined to create multipathogen detection systems of considerably broader application.

\section{MATERIALS AND METHODS}

Hosts, viruses, and RNA extraction. Potato leafroll virus (PLRV) and Potato virus $Y$ (PVY) reference isolates were maintained in potato (Solanum tuberosum) tissue culture plantlets in vitro, as described (46). The PLRV isolates from the collection at Cornell University were PLRV-Sup (in cv. Superior), PLRV-Ken (in cv. Kennebec), PLRV-WI, and PLRV\#4. The PVY isolates PVY-Mex and PVY-Oz were maintained in tissue culture in the potato cv. Russet Burbank and in the greenhouse on tobacco (Nicotiana tabacum cv. Burley), respectively. The potato cvs. Cinnabar, Buffalo, and Altura were dually infected with PLRV and PVY and maintained as tissue culture plantlets. Cucumber mosaic virus (CMV) isolates CMV-Mal1 (31) and CMV-Fny (3) were propagated in $N$. clevelandii. Total RNA was extracted from $200 \mathrm{mg}$ of leaf tissue using an RNeasy Plant mini kit (Qiagen Inc., Valencia, CA). Total RNA $(40 \mu \mathrm{l})$ was recovered and its concentration estimated by measuring absorbance at $260 \mathrm{~nm}$ (39).

Reverse transcription and cDNA amplification. Total extracted plant RNAs (host and viral) were amplified using a reverse transcription (RT)-PCR procedure based on the strategy of Bohlander et al. (4) for the nonspecific amplification of DNA of unknown sequence (Fig. 1). The RT reactions were prepared with $4 \mu \mathrm{g}$ of total RNA, $2 \mu \mathrm{M}$ random anchored primer (either 5'TGGTAGCTCTTGATCANNNNN-3' or 5'-TGGTAGCTCTTGATCANNNNNNNNN-3') or virus-specific primer, $2 \mathrm{mM}$ dNTP mix, and nuclease-free water in a volume of $10 \mu \mathrm{l}$. The mixture was heated for $5 \mathrm{~min}$ at $65^{\circ} \mathrm{C}$ and chilled on ice for $2 \mathrm{~min}$. To the chilled mixture was added $4 \mu \mathrm{l}$ of $5 \times$ first-strand buffer (Invitrogen Corp., Carlsbad, CA), $2 \mu \mathrm{l}$ of $0.1 \mathrm{M}$ dithiothreitol, $2 \mu \mathrm{l}$ of RNaseOut ribonuclease inhibitor (Invitrogen) at $40 \mathrm{U} / \mu \mathrm{l}, 1.0 \mu \mathrm{l}$ of M-MLV reverse transcriptase (Invitrogen) at $200 \mathrm{U} / \mu \mathrm{l}$, and water to a final volume of $20 \mu \mathrm{l}$. The mix was incubated at $25^{\circ} \mathrm{C}$ for $5 \mathrm{~min}, 35^{\circ} \mathrm{C}$ for $5 \mathrm{~min}$, and $37^{\circ} \mathrm{C}$ for $1 \mathrm{~h}$. For real-time or conventional RT-PCR (described below), reverse transcription with the same amount of the total RNA was done with $2 \mu \mathrm{M}$

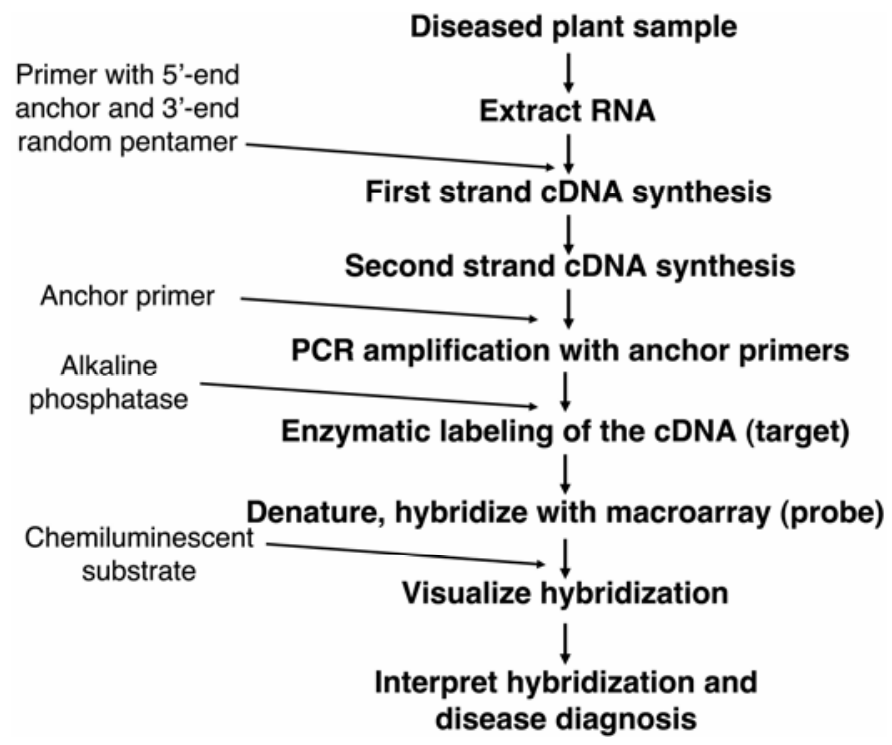

Fig. 1. Schematic outline of the strategy used in the macroarray detection of viral sequences. For clarity, the second-strand complementary DNA (cDNA) synthesis is shown as a separate step; in the standard protocol, the anchor primer is added immediately after first-strand cDNA synthesis and the second strand that will be amplified is synthesized in the first of 35 polymerase chain reaction (PCR) cycles. The outline is abbreviated, with blocking and washing steps not depicted. virus-specific primers such as $\mathrm{P} 392$ or P403, but the reaction was carried out at $42^{\circ} \mathrm{C}$ for $1 \mathrm{~h}$. In the case of the random-primed reactions, the second strand synthesis was mediated by the reverse transcriptase (48) and was carried out by denaturing the cDNA for $5 \mathrm{~min}$ at $65^{\circ} \mathrm{C}$, cooling on ice, doubling the total volume with an addition of all new RT reagents, and repeating the RT reaction conditions with the ramped temperature regime, as described above. Alternatively, the original RT reaction products were used directly in a PCR reaction and the second-strand cDNA was synthesized in the first cycle of the PCR, as described below. PCR reactions consisted of $2.5 \mu \mathrm{l}$ of reverse transcription product, $25 \mu \mathrm{l}$ of $2 \times$ iQsupermix (Bio-Rad Laboratories, Hercules, CA), $20 \mathrm{pmol}$ of anchor primer (5'-AGAGTTGGTAGCTCTTGATC-3') for anchor-primed amplification, and water to a total volume of $50 \mu \mathrm{l}$. For conventional and real-time RT-PCR, 20 pmol each of the virus-specific reverse and forward primers were added to the PCR mix instead of anchor primer. Additionally, for the real-time PCR, $10 \mathrm{pmol}$ of TaqMan probe (Applied Biosystems, Foster City, CA) also was included in the PCR mix. Anchor-primed amplification was done in a thermocycler (Mycycler; Bio-Rad) with an initial 5-min denaturation step at $94^{\circ} \mathrm{C}$; followed by 35 cycles of $94^{\circ} \mathrm{C}$ for $30 \mathrm{~s}, 40^{\circ} \mathrm{C}$ for $30 \mathrm{~s}, 50^{\circ} \mathrm{C}$ for $1 \mathrm{~min}$, and $72^{\circ} \mathrm{C}$ for $2 \mathrm{~min}$; and a final extension step at $72^{\circ} \mathrm{C}$ for $7 \mathrm{~min}$. For virus-specific amplification, the PCR profile was an initial 5-min denaturation step at $94^{\circ} \mathrm{C}$; followed by 35 cycles of $94^{\circ} \mathrm{C}$ for $30 \mathrm{~s}, 52^{\circ} \mathrm{C}$ for $30 \mathrm{~s}$, and $72^{\circ} \mathrm{C}$ for $1 \mathrm{~min}$; and a final extension step at $72^{\circ} \mathrm{C}$ for $7 \mathrm{~min}$. For the real-time PCR, the PCR profile was an initial $5 \mathrm{~min}$ denaturation step at $94^{\circ} \mathrm{C}$, followed by 35 cycles of $94^{\circ} \mathrm{C}$ for $30 \mathrm{~s}$, $52^{\circ} \mathrm{C}$ for $30 \mathrm{~s}$, and $72^{\circ} \mathrm{C}$ for $30 \mathrm{~s}$.

Agarose gel electrophoresis, purification, and quantification of PCR products. Unpurified PCR products ( $5 \mu \mathrm{l}$ each) and a comparable amount of the reverse transcription products used as input for the PCR reactions were analyzed on a $1.2 \%$ agarose gel in $0.5 \times$ Tris-acetate EDTA (TAE) buffer $(0.02 \mathrm{M}$ Tris-acetate, $0.5 \mathrm{mM}$ EDTA, $\mathrm{pH}$ 8.0) with ethidium bromide staining. PCR products were purified using a QIAquick PCR purification kit (Qiagen) and the amount of product estimated by absorbance at $260 \mathrm{~nm}$ (39).

RT-PCR and real-time quantification of PLRV. For conventional RT-PCR, a 725-bp nucleotide sequence from PLRV (nucleotides 3426 to 4129; reference GenBank accession no. AF453394) was amplified using the forward primer P402 (5'TCAAGCCTCGTTACATCAACCGGA- $3^{\prime}$ ) and the reverse primer P403 (5'-TAATACGACTCACTATAGGGAAAGAGTATTTCCCTTCCACAGTATCCGGCA-3'); P403 contained a T-7 promoter sequence at its $5^{\prime}$ end. The amplified cDNA contained the target sequences of the real-time primers, and was transcribed using an mMessage mMachine transcription kit and protocol (Ambion, Inc., Austin, TX). The cRNA was recovered using the lithium chloride precipitation option in the manufacturer's protocol. The quantity and the copy number of the cRNA was estimated as described by Olmos et al. (32). The quantity of cRNA ( $\mu \mathrm{g})$ obtained was quantified by UV absorption at $260 \mathrm{~nm}$ (39). The number of bases $\left(N_{b}\right)$ in the cRNA transcript was 725 and, from its estimated molecular weight (assuming $340 \mathrm{Da}$ per ribonucleotide), the quantity of cRNA per picomole was calculated as follows: pmol of single-stranded RNA $=\mu \mathrm{g}$ (of single-stranded RNA) $\times$ $\left(10^{6} \mathrm{pg} / \mu \mathrm{g}\right) \times(1 \mathrm{pmol} / 340 \mathrm{pg}) \times\left(1 / N_{b}\right)$. Using the Avogadro constant $\left(6.03 \times 10^{23}\right.$ molecules $\left./ \mathrm{mol}\right)$, the copy number of cRNA transcripts was calculated per $1 \mu \mathrm{l}$, the volume template used in each of the real-time RT-PCR reactions. Ten-fold serial dilutions of the transcripts were prepared starting from an initial $4.2 \times 10^{9}$ copies (cRNA at $1.86 \mathrm{ng} / \mu \mathrm{l}$ ) to $4.2 \times 10^{0}$ copies per reverse transcription reaction to generate a standard curve. The copy number of PLRV in samples was estimated from the quantity of cRNA in grams as described by Olmos et. al. (32) and Ginocchio et al. (18). Real-time RT-PCR was done with the various cRNA amounts and a standard curve (cRNA copy number versus 
threshold cycle $[\mathrm{Ct}]$ ) was generated. The primer pair and Taq Man probe used were forward primer P393 (5'-CAATCGCCGCTCAAGAAAGAA-3'), reverse primer P392 (5'-GGTTGTCCTTTGTAACACGAATG-3'), and probe P460 (5'-6-FAM-TGAGCCTCGTCCTCGGGGAACTCC-BHQ-3'). The copy number of PLRV RNA in the total RNA of infected-plant extract was determined using the standard curve. To estimate the PLRV copy number in $4 \mu \mathrm{g}$ of total RNA, real-time RT-PCR was done with $4 \mu \mathrm{g}$, $0.4 \mu \mathrm{g}$, and $40 \mathrm{ng}$ of the total RNA, and the Ct values of these dilutions within the standard curve were used for the estimation.

Oligonucleotide probes. Probes of $\approx 70$ nucleotides were designed for the detection of PLRV, CMV, and PVY. Complete genomic sequences of each of the viruses were retrieved from the National Center for Biotechnology Information (NCBI) database (available online from NCBI website) and aligned using Vector NTI Suite 8 (InforMax, Inc., Frederick, MD). Regions of sequence identity conserved among most or all strains of the virus were identified visually and used for the design of 70-mer oligo- nucleotides. As positive or reference controls, seven 70-mer probes corresponding to conserved host plant ribosomal RNAs (rRNAs) were designed, one for the 5.8S rRNA, three for the 18S rRNA, and three for the 25S RNA. The oligo Analyzer 3.0 tools (Integrated DNA Technologies, Coralville, IA) were used for analysis of $\mathrm{G}+\mathrm{C}$ content and temperature $\left(\mathrm{T}_{\mathrm{m}}\right)$, and to predict hairpin formation and self-annealing properties of each oligonucleotide. Those oligonucleotides selected exhibited $\mathrm{T}_{\mathrm{m}}$ of $\approx 70^{\circ} \mathrm{C}$, the least tendency to form homo dimers, and the least stable hairpin structures. The virus specificity of each of these oligonucleotides was evaluated using the Basic Local Alignment Search Tool (BLAST) (2). Oligonucleotides were synthesized commercially (Integrated DNA Technologies, Coralville, IA), and the viral- and rRNA-specific oligonucleotides are listed in Table 1.

Printing of oligonucleotide probes on membranes. Ribosomal and virus-specific DNA oligonucleotide probes were diluted to 10 and $20 \mu \mathrm{M}$, respectively, in $1 \times$ spotting buffer $(4 \mu \mathrm{M}$ sodium carbonate buffer, $\mathrm{pH} 8.0 ; 3 \times \mathrm{SSC}[1 \times \mathrm{SSC}$ is $0.15 \mathrm{M}$

TABLE 1. Sequences of DNA oligonucleotide probes used in the macroarray

\begin{tabular}{|c|c|c|}
\hline Probe $^{\mathrm{a}}$ & Sequence & $\begin{array}{c}\text { Nucleotide } \\
\text { position }\end{array}$ \\
\hline-1 & ГАТ CTC GGC & $289^{\mathrm{b}}$ \\
\hline & TCG GGG GCA TTC GTA TTT CAT AGT CAG AGG TGA AAT TCT TGG ATT TAT GAA AGA CGA ACA ACT GCG AAA G & $857-926^{c}$ \\
\hline NA-3 & TCT ATG GGT GGT GGT GCA TGG CCG TTC TTA GTT GGT GGA GCG ATT TGT CTG GTT AAT TCC GTT AAC GAA C & $1242-1311^{\mathrm{c}}$ \\
\hline & TCA GCT CGC GTT GAC TAC GTC CCT GCC CTT TGT ACA CAC CGC CCG TCG CTC CTA CCG ATT GAA TGG TCC G & $1586-1655^{\mathrm{c}}$ \\
\hline RNA-5 & AGG CTC GAA GCG ATA CTG ACG TGC AAA TCG TTC GTC TGA CTT GGG TAT AGG GGC GAA AGA CTA ATC GAA C & $858-927^{\mathrm{d}}$ \\
\hline RNA-6 & GTG ACG CGC ATG AAT GGA TTA ACG AGA TTC CCA CTG TCC CTG TCT ACT ATC CAG CGA AAC CAC AGC CAA G & $352-42^{\mathrm{d}}$ \\
\hline RNA-7 & GGA CGG TGG TCA TGG AAG TCG AAA TCC GCT AAG GAG TGT GTA ACA ACT CAC CTG CCG AAT CAA CTA GCC C & $1200-1299^{d}$ \\
\hline VY-1 & AAT TAA AAC AAC TCA ATA CAA CAT AAG AAA AAC AAC GCA AAA ACA CTC ATA AAC GCT TAT TCT CAC TCA A & $2-70^{\mathrm{e}}$ \\
\hline VY-2 & GCA TAC GAC ATA GGA GAA ACT GAG ATG CCA ACT GTG ATG AAT GGG CTT ATG GTT TGG TGC ATT GAA AAT G & $8878-8947^{\mathrm{e}}$ \\
\hline VY-3 & ATG CCA ACT GTG ATG AAT GGG CTT ATG GTT TGG TGC ATT GAA AAT GGA ACC TCG CCA AAT GTC AAC GGA G & $897^{\mathrm{e}}$ \\
\hline VY-4 & GGC TTA TGG TTT GGT GCA TTG AAA ATG GAA CCT CGC CAA ATG TCA ACG GAG TTT GGG TTA TGA TGG ATG G & $-8990^{\mathrm{e}}$ \\
\hline VY-5 & C CAA CCC TTA GGC AAA TCA TGG CAC ATT TCT CAG ATG TTG CAG A & $9083^{\mathrm{e}}$ \\
\hline VY-6 & ACC CTT AGG CAA ATC ATG GCA CAT TTC TCA GAT GTT GCA GAA GCG TAT ATA GAA ATG CGC AAC AAA AAG G & $9112^{\mathrm{e}}$ \\
\hline VY-7 & CTC AGA TGT TGC AGA AGC GTA & $138^{\mathrm{e}}$ \\
\hline VY-8 & CTC GAC TTT TCG GGT TGG ACG GTG GCA TCA GTA CAC AAG AGG AGA ACA CAG AGA GGC ACA CCA CCG AGG A & 9339 e \\
\hline VY-9 & GGA TGT CTC TCC AAG TAT GCA TAC TC & $9385^{\mathrm{e}}$ \\
\hline VY-10 & GTC TCT CCG GAC GAT ATA TAA ATA TTT ACA TAT GCA GTA AGT ATT TTG GCT TTT CCT GTA CTA CTT TTA T & $-9461^{\mathrm{e}}$ \\
\hline Y-11 & TGT ACT ACT TTT ATC & $9293^{\mathrm{e}}$ \\
\hline VY-12 & TCT GGA TCT ATC TGC TTG GGT GAT GTT GTG ATT TTG TCA TAA CAG TGA CTG TAA ACT TCA ATC A & $-9715^{\mathrm{e}}$ \\
\hline MV-1 & AAT TCC TA & $187^{\mathrm{f}}$ \\
\hline-2 & ICT GGT GCC CTC CGC TTG TG & $-386^{\mathrm{f}}$ \\
\hline & GC AGG ACC TC & $450^{\mathrm{f}}$ \\
\hline MV-4 & TTC TTA CTC TCT GAC G & $-2046^{\mathrm{g}}$ \\
\hline & GAA CGG GT & $2887^{\mathrm{g}}$ \\
\hline MV-6 & TCT GAC GAT CTT CAA A & $189^{\mathrm{h}}$ \\
\hline MV-7 & GAT TCA GTC ACG GAA TAT GAT AAG AAG CTT GTT TCG CGC ATT CAA ATT CGA GTT AAT CCT TTG CCG AAA T & $1536-1605^{\mathrm{h}}$ \\
\hline MV-8 & CGC ATT CAA ATT CGA GTT AAT CCT TTG CCG AAA TTT GAT TCT ACC GTG TGG G & $1557-1626^{\mathrm{h}}$ \\
\hline MV-9 & GTT GTT GCG CGG GGA ACG GGT TGT CCA TCC AGC TTA CG & $1999-2058^{\mathrm{h}}$ \\
\hline CMV-10 & TTT TTA CGG TGA ACG GGT TGT CCA TC & $-2071^{\mathrm{h}}$ \\
\hline MV-11 & CAT CAT TGG AT & $222-291^{\mathrm{h}}$ \\
\hline MV-12 & CGC GCA TTC AAA TTC GAG TTA ATC CTT TGC CGA AAT TTG ATT CTA CCC & $-1639^{\mathrm{h}}$ \\
\hline LRV-1 & GGT TGT ATA ACC AGC TTG ATC TAC & $-716^{\mathrm{i}}$ \\
\hline PLRV-2 & CAA AGC CTG AAT CTA CAG GCT GC & $-2142^{\mathrm{i}}$ \\
\hline PLRV-3 & TCC AGT CCC TTG AGC TAG ACG CTG GTG TAG GCA TTC CCT ATA T & $2278-2347^{\mathrm{i}}$ \\
\hline PLRV-4 & GTT TCC TTG GTG GA & $-2644^{\mathrm{i}}$ \\
\hline PLRV-5 & CCA GTG GTT GGT TCC GAG TGC CAC CAC AAA AGA ACA CTG AAG GAG C & $3327-3396^{i}$ \\
\hline PLR -6 & CGC CGC TCA AGA AGA ACT GGA GTT CC & $3819^{\mathrm{i}}$ \\
\hline PLRV-7 & CCC AAG GAA GTT TCA CCT TCG GGC CGA GTC TAT CAG ACT GTC CGG CAT TCA AGG ATG GAA TAC TCA AGG C & $3835-3904^{\mathrm{i}}$ \\
\hline PLRV-8 & TAC TCA AGG CCT ACC ATG AGT ATA AGA TCA CAA GCA TCT TAC TTC AGT TCG TCA & $3964^{\mathrm{i}}$ \\
\hline PLRV-9 & GAC CCT GGT TAT TCC AAA GAA GAT GTC GCT GCT GCA ACT ATT ATA GCG CAC GGC AGT ATT CAA GAT GGG C & $5289-538^{i}$ \\
\hline PLRV-10 & CCG GAC ATT AAG CGG AAC GAA AGC CGA AAG GTG ATT AGG CTC TCA ACG CCT GCT AGA GAC CGT CGA AAG & $5772-5841^{\mathrm{i}}$ \\
\hline PLRV-11 & CTC GAT GAA GGC CGC TAC CTC CTC ATC ATG TCT GTT TCC TTG GTG GAT CAA CTG GTA GCC CGG GTT CTG T & $2548-2617^{\mathrm{i}}$ \\
\hline PLRV-12 & CCT CGC CGT TCC GGT CAA TAC CAA CAA AAT GCT TTA CAA GTT GAT CCA TGG TTA TAA TCC GGA ATG TGG C & $3192-3261^{\mathrm{i}}$ \\
\hline
\end{tabular}

\footnotetext{
${ }^{a}$ rRNA = ribosomal RNA, PVY = Potato virus $Y, \mathrm{CMV}=$ Cucumber mosaic virus, and PLRV = Potato leaf roll virus .

b GenBank accession number of 5.8S rRNA used to designate probe nucleotide position is U46615.

c GenBank accession number of 18S rRNA used to designate probe nucleotide position is U42796.

d GenBank accession number of 25S rRNA used to designate probe nucleotide position is M11585.

e GenBank accession number of the PVY reference genome used to designate probe nucleotide position is U09509.

${ }^{f}$ GenBank accession number of the CMV RNA 1 reference used to designate probe nucleotide position is NC_002034.

g GenBank accession number of the CMV RNA 2 reference genome used to designate probe nucleotide position is NC_002035.

${ }^{\mathrm{h}}$ GenBank accession number of the CMV RNA 3 reference genome used to designate probe nucleotide position is D10538.

i GenBank accession number of the PLRV reference genome used to designate probe nucleotide position is AY138970.
} 
$\mathrm{NaCl}$ and $0.15 \mathrm{M}$ sodium citrate]; $50 \%$ [vol/vol] dimethy sulfoxide [DMSO]; $0.01 \% \mathrm{~N}$-lauroylsarcosine; and $1 \mathrm{mg}$ of bromophenol blue). The probes were transferred in 30- $\mu$ l aliquots into the wells of a polypropylene 384-well microtiter plate (Nalge Nunc International, Rochester, NY). A pin replicator (VP 110; V\&P Scientific, Inc., San Diego, CA) for 384-well plates was cleansed as recommended by its manufacturer prior to printing. Hybond-N Plus membranes (GE Healthcare Bio-Sciences Corp., Piscataway, NJ) were cut to the size $(12$ by $10 \mathrm{~mm})$ of a multiprint device (VP 381; V\&P Scientific) and the copier unit (VP 382; V\&P Scientific) aligned over the 384-well plate. The oligonucleotides were printed on a membrane on the same spots twice. The pin replicator delivered $\approx 0.2 \mu \mathrm{l}$ per print. Five minutes was allowed for air drying the membrane before the second printing. The printed oligonucleotides were fixed onto the membrane by UV-cross-linking for $2 \mathrm{~min}$ at $120 \mathrm{~mJ} / \mathrm{s}$ in a Stratalinker (Strategene Corp., La Jolla, CA).

Labeling, hybridization, and detection. The chemical labeling of the purified PCR product was done using an AlkPhos Direct labeling kit (GE Healthcare Bio-Sciences Corp.), following the manufacturer's protocol, except that $200 \mathrm{ng}$ of DNA was labeled with $1 \mu \mathrm{l}$ of the alkaline phosphatase reagent. Prehybridization and hybridization were done at $55^{\circ} \mathrm{C}$ using the hybridization protocol provided with the Alkphos Direct kit. Prehybridization and hybridization were done in 50-ml polypropylene tubes (Corning, Inc., Corning, NY). Prior to adding the prehybridization buffer, membranes first were wetted by incubating in $0.5 \%$ sodium dodecyl sulfate (SDS) $(\mathrm{wt} / \mathrm{vol})$ at $55^{\circ} \mathrm{C}$ for $1 \mathrm{~h}$ followed

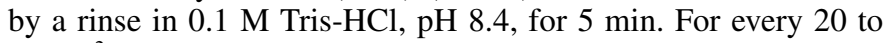
$25 \mathrm{~cm}^{2}, 10 \mathrm{ml}$ of hybridization buffer was used for blocking at $55^{\circ} \mathrm{C}$ for at least $1 \mathrm{~h}$. After this prehybridization, only $5 \mathrm{ml}$ of the buffer was used for hybridization with 200-ng labeled target DNA. Hybridization was done at $55^{\circ} \mathrm{C}$ overnight. Membranes were washed two times in a primary wash buffer $(2 \mathrm{M}$ urea, $0.1 \%$ SDS, $50 \mathrm{mM}$ sodium phosphate, $150 \mathrm{mM} \mathrm{NaCl}$, and $0.2 \%$ [wt/vol] blocking agent [supplied with the Alkphos Direct kit]) at $55^{\circ} \mathrm{C}$ for $15 \mathrm{~min}$ each, followed by a washing in a secondary wash buffer (50 mM Tris, $100 \mathrm{mM} \mathrm{NaCl}, \mathrm{pH} \mathrm{10.0)}$ for $10 \mathrm{~min}$, at room temperature on a shaker. The membranes were incubated with


Fig. 2. Representative polymerase chain reaction (PCR) amplification products, using as templates first- and second-strand complementary DNAs (cDNAs) synthesized with primers consisting of random pentamers linked to a $5^{\prime}$ end anchor sequence. $M=$ DNA ladder of molecular size markers. Lanes 1 to 8 : cDNAs amplified from eight independent RNA preparations. Lanes 9 to 12: Four reverse-transcriptase (RT) reaction products, which were used as substrates for the PCR reactions depicted in lanes 1 to 4 , respectively. The volume of the RT reaction product loaded in each lane of the gel was equivalent to the amount of input cDNA added in the lanes for the corresponding PCR products. The RNAs employed were isolated from infected Solanum tuberosum (potato; lanes 1, 2, 5, 6, 7, 8, 9, and 10), Nicotiana clevelandii (lanes 3 and 11), and N. tabacum (tobacco; lanes 4 and 12).
CDP-star chemiluminescent (GE Healthcare Bio-Sciences Corp.) reagent for $5 \mathrm{~min}$, drained, and exposed to Chemiluminescence Bio Max film (Kodak Co., Rochester, NY) for $1 \mathrm{~h}$ to overnight.

Comparing the sensitivity of the macroarray, double-antibody sandwich ELISA, PCR, and real-time PCR. For comparison of double-antibody sandwich (DAS)-ELISA with the PCRbased techniques, uninfected or PLRV-infected potato leaf tissue was sliced into 1-mm-wide pieces and divided into two equal portions of $200 \mathrm{mg}$ each. One half of the sample was extracted for total RNA as described above, while the other half sample was processed for serological analysis by grinding in $2 \mathrm{ml}$ extraction/ conjugate buffer (phosphate buffered saline [39] containing 2\% polyvinylpyrrolidone, molecular weight 40,000 , and $0.1 \%$ ovalbumin). For DAS-ELISA (12), the original PLRV-WI leaf extract was designated $1 \times$ and diluted serially into $1 \times$ healthy leaf tissue extract to yield dilutions of $1 / 5 \times, 1 / 25 \times, 1 / 125 \times, 1 / 625 \times$ and $1 / 3,125 \times$ or, alternatively, $10^{-1} \times$ through $10^{-5} \times$. These extracts were tested for the presence of PLRV by using commercial antibodies at recommended dilutions (Agdia, Inc., Elkhart, IN). For RNA analysis to determine the dilution end-point of detection, the RNA concentration was estimated and $4 \mu \mathrm{g}$ of total RNA extract $(\approx 2 \mu \mathrm{l})$ from the infected plant was diluted into an uninfected plant RNA extract to obtain a 10 -fold dilution series. For macroarray analyses, $2 \mu \mathrm{l}$ of each of the total RNA dilutions were amplified by random-primed RT-PCR, as described above, and these products then were labeled and hybridized to membranes. In parallel, conventional RT-PCR and real-time PCR were performed using equivalent volumes of the diluted RNAs. For the purposes of comparing sensitivities, assuming $80 \mu \mathrm{g}$ of total RNA extracted from $200 \mathrm{mg}$ of infected tissue, the $4 \mu \mathrm{g}$ of undiluted RNA used for the PCR assays would correspond to a starting $10 \mathrm{mg}$ of leaf tissue. Similarly, for the DAS-ELISA, one well of the microtiter plate with $100 \mu \mathrm{l}$ of the undiluted ground extract $(200 \mathrm{mg}$ of leaf tissues in $2 \mathrm{ml}$ of buffer) would correspond to $10 \mathrm{mg}$ of tissue.

\section{RESULTS}

Amplification of total RNA from virus-infected plants. Total RNAs from virus-infected plants were amplified in a relatively unbiased fashion, as shown schematically in Figure 1. cDNA synthesis was primed using random pentamers (or nonamers) linked to the $3^{\prime}$ end of an anchor primer of a specific sequence. The same primer was used to prime second-strand cDNA synthesis, giving rise to products bound at either end harboring the anchor primer sequence. The cDNAs then were added to a reaction mixture with the anchor primer for PCR amplification. The products of three independent amplification experiments initially primed with random pentamers are shown in Figure 2. cDNAs from eight independent preparations of total RNAs from leaf tissues of potato, $N$. clevelandii, and $N$. tabacum are represented. The amplification products were visualized as a smear of products co-migrating with molecular size markers from 300 to $500 \mathrm{bp}$ up to the well of the gel; faint specific bands also were observed against the background smear. Similar results were obtained if the second-strand cDNA was synthesized in a separate reaction with the random primers alone prior to PCR amplification. Comparable results also were obtained using random nonamers instead of pentamers. The faint bands are presumed to represent host sequences recognized and amplified by the anchor primers, but the same bands were not always observed in every reaction. Thus, the total plant RNAs appear to be amplified in a relatively unbiased fashion.

The design of virus- and host-specific probes. Twelve oligonucleotides specific to each of the three viruses CMV, PVY, and PLRV were synthesized for spotting onto nylon membranes. Each of the oligonucleotides corresponded and were referenced to the genomic sequences of CMV-Fny $(33,35,36)$, PVY-O (44), or an un-named isolate of PLRV (Table 1). The oligonucleotides 
selected were those with $>95 \%$ sequence identity to the target of interest and with $<14 \%$ contiguous and $21 \%$ noncontiguous sequence identity to unrelated sequences. The oligonucleotides represented different regions of each virus genome, and preference was given to those with $\mathrm{G}+\mathrm{C}$ content of between 40 and $60 \%$. Based on sequence alignments and BLAST analyses, the oligonucleotides were expected to hybridize to all isolates of the respective virus, but not to host plant-derived nucleic acids. Oligonucleotides specific to plant rRNA were synthesized for inclusion on the array in order to serve as internal controls to monitor the relative intensity of hybridization signals from experiment to experiment. Seven rRNA-specific 70 mers were designed to hybridize with conserved $5 \mathrm{~S}, 18 \mathrm{~S}$, and $25 \mathrm{~S}$ rRNA sequences present in monocotyledonous and dicotyledonous plants and were spotted along the first row and first column of the nylon membrane (Fig. 3A).

Labeling and hybridization of target DNA to oligonucleotide probes on the macroarray. The amplified cDNAs from virus-infected and uninfected control plants were chemically labeled by conjugation with a heat-stable alkaline phosphatase. Target DNA hybridization to oligonucleotide probes spotted onto nylon membranes was visualized by incubation with a chemiluminescent substrate and exposure to film. The placement of the rRNA-specific 70 mers along the top and sides of the membrane facilitated identifying the rows and columns of spotted oligonucleotides and provided a reference for the relative strength of the hybridization signals (Fig. 3B to D). Each spot contained an estimated $8 \mathrm{pmol}$ of viral-specific oligonucleotide or 4 pmol of rRNA-specific oligonucleotide. All of the rRNA-specific oligonucleotides hybridized to the labeled target, although the probes rRNA-1 and rRNA-5 yielded weaker hybridization signals and were not visualized in some experiments. The remaining five rDNA probes were clearly visualized in all experiments.

All three viruses were easily detected in the macroarray, with strong signals observed relative to the background on the membranes (Fig. 3B to D). The labeled target DNA hybridizations were specific to the infecting virus, with no observed cross hybridization to probes for heterologous viruses. Similarly, labeled
A

\begin{tabular}{|c|c|c|c|c|c|c|c|c|}
\hline$\cdot$ & a & $\mathrm{b}$ & C & $\mathrm{d}$ & e & f & $\mathrm{g}$ & h \\
\hline 1 & $\bullet$ & & $\bullet$ & $\bullet$ & $\bullet$ & $\bullet$ & $\bullet$ & $\bullet$ \\
\hline & R1 & & R2 & R3 & R4 & R5 & R6 & R7 \\
\hline 2 & $\bullet$ & & & & & & & \\
\hline 2 & R1 & & $\bullet$ & $\bullet$ & $\bullet$ & & & \\
\hline 3 & $\bullet$ & & $\bullet$ & $\bullet$ & $\bullet$ & $\stackrel{\bullet}{\text { Li }}$ & $\bullet$ & P1 \\
\hline 4 & $\bullet$ & & $\bullet$ & $\bullet$ & $\bullet$ & $\bullet$ & $\bullet$ & $\bullet$ \\
\hline & R2 & & L2 & $\mathrm{C} 2$ & P2 & L2 & $\mathrm{C} 2$ & P2 \\
\hline 5 & $\bullet$ & & $\bullet$ & $\bullet$ & $\bullet$ & $\bullet$ & $\bullet$ & $\bullet$ \\
\hline & R3 & & L3 & C3 & P3 & L3 & $\mathrm{C} 3$ & P3 \\
\hline 6 & $\bullet$ & & $\bullet$ & $\bullet$ & $\bullet$ & $\bullet$ & $\bullet$ & $\bullet$ \\
\hline & R3 & & L4 & $\mathrm{C} 4$ & P4 & $\mathrm{L} 4$ & $\mathrm{C} 4$ & P4 \\
\hline 7 & $\bullet$ & & $\bullet$ & $\bullet$ & $\bullet$ & $\bullet$ & $\bullet$ & $\bullet$ \\
\hline & R4 & & L5 & C5 & P5 & L5 & C5 & P5 \\
\hline 8 & $\bullet$ & & $\bullet$ & $\bullet$ & $\bullet$ & $\bullet$ & $\bullet$ & $\bullet$ \\
\hline & R4 & & L6 & C6 & P6 & L6 & C6 & P6 \\
\hline 9 & $\bullet$ & & $\bullet$ & $\bullet$ & $\bullet$ & $\bullet$ & $\bullet$ & $\bullet$ \\
\hline & R5 & & L7 & C7 & P7 & L7 & C7 & P7 \\
\hline 10 & $\bullet$ & & $\bullet$ & $\bullet$ & $\bullet$ & $\bullet$ & $\bullet$ & $\bullet$ \\
\hline & R5 & & L8 & C8 & P8 & L8 & C8 & P8 \\
\hline 11 & $\bullet$ & & $\bullet$ & $\bullet$ & $\bullet$ & $\bullet$ & $\bullet$ & $\bullet$ \\
\hline & R6 & & L9 & C9 & P9 & L9 & C9 & P9 \\
\hline 12 & $\bullet$ & & $\bullet$ & $\bullet$ & $\bullet$ & $\bullet$ & $\bullet$ & $\bullet$ \\
\hline & R6 & & L10 & $\mathrm{C} 10$ & $\mathrm{P} 10$ & L10 & $\mathrm{C} 10$ & $\mathrm{P} 10$ \\
\hline 13 & $\bullet$ & & $\bullet$ & $\bullet$ & $\bullet$ & $\bullet$ & $\bullet$ & $\bullet$ \\
\hline & $\mathrm{R} 7$ & & L11 & $\mathrm{C} 11$ & P11 & L11 & Cl1 & P11 \\
\hline 14 & $\bullet$ & & $\bullet$ & $\bullet$ & $\bullet$ & $\bullet$ & $\bullet$ & $\bullet$ \\
\hline & R7 & & L12 & $\mathrm{C} 12$ & P12 & L12 & $\mathrm{C} 12$ & P12 \\
\hline
\end{tabular}

B

a b c d e f g h

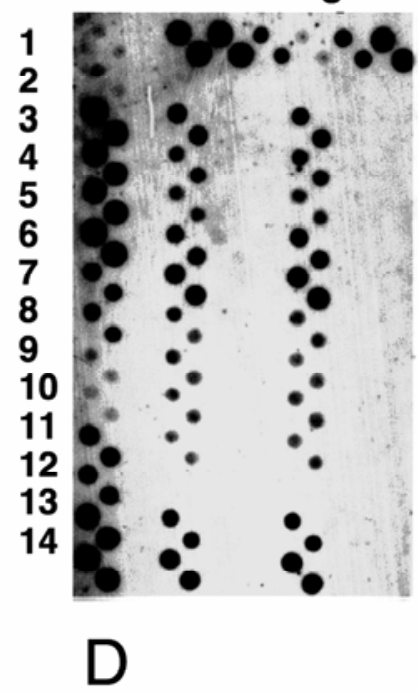

a b c d e f g h

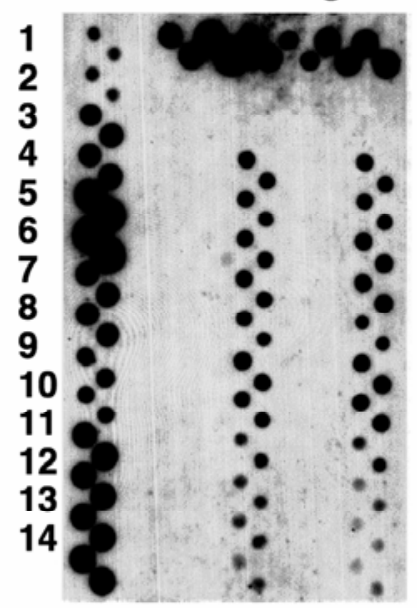

G

a b c d e f g h

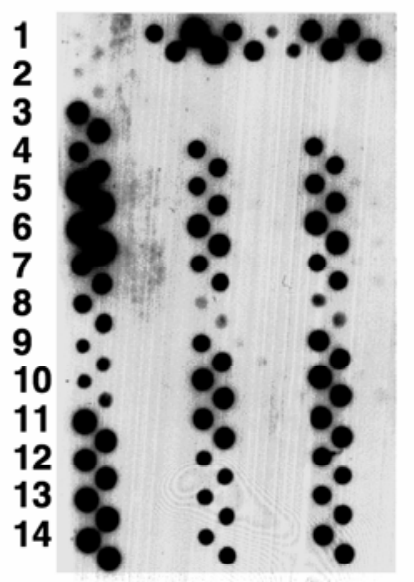

E

a b c d e f g h

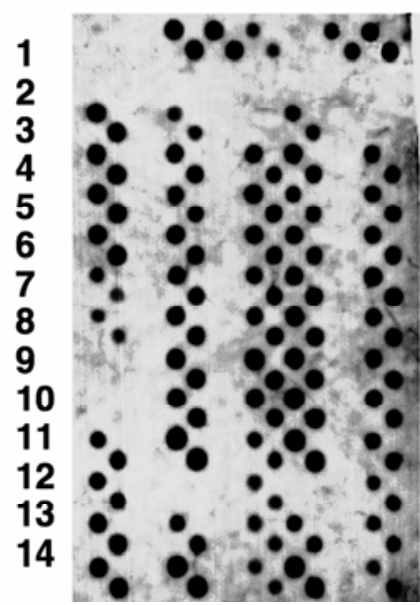

Fig. 3. Macroarray detection of Cucumber mosaic virus (CMV), Potato virus Y (PVY), and Potato leafroll virus (PLRV) in single and double infections. A, Diagram of the spotting pattern of 70-mer DNA oligonucleotide probes. In each box (e.g., 1a, 1b, 1c, and so on) there are two identical, diagonally spotted oligonucleotides. Ribosomal RNA-specific oligonucleotide reference controls were coded R1, R2, R3, and so on. PLRV-, CMV-, and PVY-specific oligonucleotides were similarly coded L1 to L12, C1 to C12 and P1 to P12, respectively. B to E, Films exposed to hybridized macroarrays for 1 to 3 h, showing the hybridization of polymerase chain reaction-amplified and labeled complementary DNA targets. The RNAs used to prepare the amplified targets were derived from B, Solanum tuberosum infected with PLRV strain WI; C, Nicotiana clevelandii infected with CMV strain Mal-1; D, N. tabacum infected with PVY strain Oz; and E, S. tuberosum doubly infected with PLRV and PVY. 
cDNAs from uninfected plants only hybridized with the reference rDNA probes (data not shown). For the detection of PLRV in potato, all of the virus-specific oligonucleotides hybridized with target cDNA except for probe PLRV-10 (Fig. 3B). This was true for experiments with target cDNA obtained from plants singly infected with four different isolates of PLRV and from plants doubly infected with both PLRV and PVY (Fig. 3E; Table 2). Two strains of CMV representing different genetic subgroups were tested on the array (Fig. 3C; Table 2). Labeled cDNAs from $N$. clevelandii infected with CMV-Mall hybridized to all the virus-specific oligonucleotides except probe CMV-1; additionally, hybridization to probe CMV-6 was very weak. In contrast, labeled cDNAs from $N$. clevelandii infected with the genetically distinct CMV-Fny hybridized to all the probes, but the signals from hybridization with probes CMV-9 and CMV-10 were relatively weak (data not shown). Labeled cDNAs from N. tabacum and $S$. tuberosum infected with strains of PVY singly or as mixed infections hybridized to all the virus-specific oligonucleotides except probe PVY-1 (Fig. 3D and E; Table 2). In all cases, probes PVY-9, -10, -11, and -12 yielded signals that were weaker than the others, but clearly distinguishable as positive. In total, PLRV was detected in seven of seven plants tested, CMV in two of two plants, and PVY in six of six plants.

Sensitivity of macroarray detection compared with DASELISA, RT-PCR, and real-time RT-PCR. The relative sensitivity of the macroarray was compared with that of three commonly used assays for plant RNA viruses: DAS-ELISA, conventional RT-PCR, and real-time RT-PCR (Fig. 4). In testing for PLRV in S. tuberosum, a 10-fold dilution series was prepared of an infected plant RNA (or sap) extract in an uninfected plant RNA (or sap) extract. The end point of detection in the macroarray was $10^{-2}$ (Fig. 4B), comparable with results obtained with the DAS-ELISA (Fig. 4C). Conventional RT-PCR was three orders of magnitude more sensitive, with an end point of detection of $10^{-2}$ (Fig. 4A). These levels of detection were observed in two independent experiments using plants infected by either isolate PLRV\#4 or PLRV-WI. In real-time RT-PCR analyses of the infected plant RNA extracts, the endpoint of detection was $10^{-7}$ in two independent experiments, a further improvement of two orders of magnitude. In order to estimate the viral copy number being detected in these assays, a 10-fold dilution series of a PLRV RNA transcript was employed in real-time RT-PCR experiments and the data were used to prepare a standard curve. These quantitative PCR measurements showed that the minimum copy number of PLRV template detected was $2 \times 10^{2}$ for real-time RT-PCR and $2 \times 10^{4}$ for the conventional RT-PCR. Furthermore, in the macroarray experiments, PLRV was detected only if there were at least $2 \times 10^{6}$ copies of the viral RNA per $4 \mu \mathrm{g}$ of total RNA (data not shown). The quantitative PCR measurements also were employed to estimate the copy number of viral RNA in sample preparations before and after the standard amplification procedure for the macroarray. In the starting aliquot of $4 \mu \mathrm{g}$ of total RNA, there were an estimated $2 \times 10^{9}$ copies of viral RNA. Following amplification, the copy number increased 100 to 1,000 -fold to between $2 \times 10^{11}$ and $2 \times 10^{12}$.

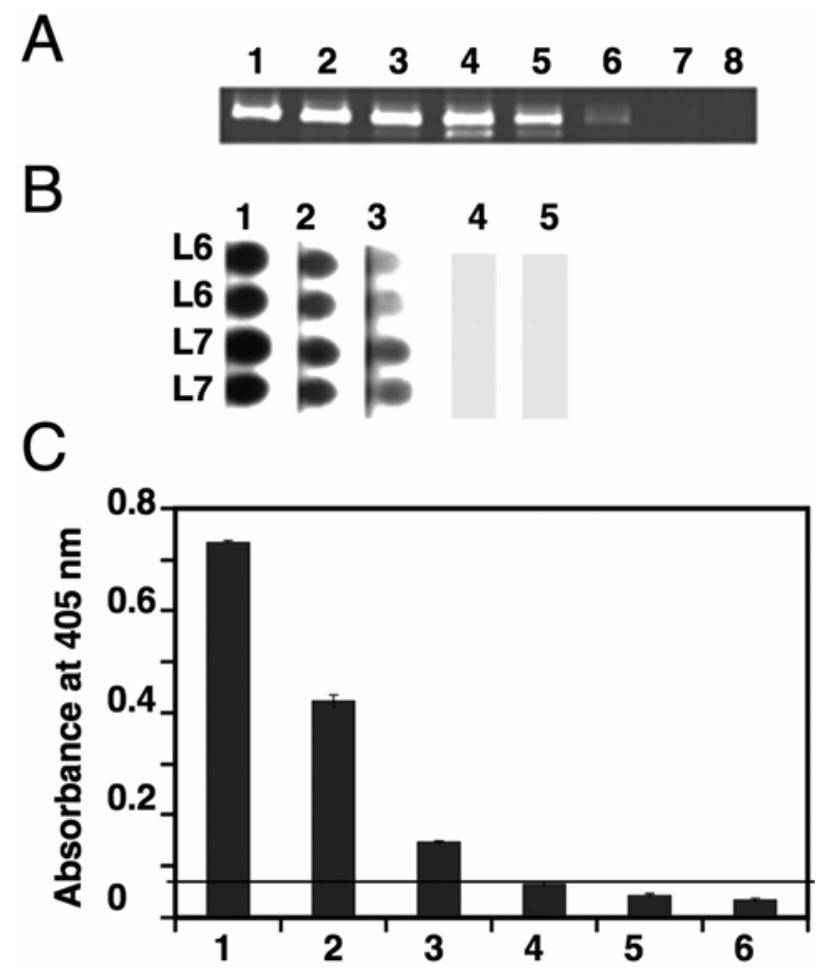

Fig. 4. Comparison of the sensitivity of detection of Potato leafroll virus (PLRV) isolate 4 by reverse-transcriptase polymerase chain reaction (RTPCR), macroarray, and double-antibody sandwich enzyme-linked immunosorbent assay (DAS-ELISA). A, Agarose gel electrophoresis and ethidium bromide stained RT-PCR products. Lanes 1 to 8 show the products from reactions performed using a dilution series of the RNA template, from 1 (undiluted) to $10^{-7}$, respectively. B, Portion of the macroarray showing hybridization to spots of 70-mer oligonucleotides L6 and L7. Columns 1 to 5 represent hybridizations performed using labeled targets prepared using an undiluted virus-infected plant RNA extract or dilutions of $10^{-1}$ to $10^{-4}$, respectively. C, Histogram showing results from a DAS-ELISA with values for absorption at $405 \mathrm{~nm}$. Bar 1 is the undiluted plant extract, and bars 2 to 6 represent dilutions of the same extract of $10^{-1}$ to $10^{-5}$, respectively. The horizontal line at an absorbance of 0.07 indicates the threshold level of detection (i.e., three standard deviations above the mean value for uninfected controls).

TABLE 2. Macroarray and double-antibody sandwich enzyme-linked immunosorbent assay (ELISA) detection of three plant viruses

\begin{tabular}{|c|c|c|c|c|c|c|c|}
\hline \multirow[b]{3}{*}{ Virus isolate } & \multirow[b]{3}{*}{ Plant source } & \multicolumn{6}{|c|}{ Diagnostic assay $^{\mathrm{a}}$} \\
\hline & & \multicolumn{2}{|c|}{ PLRV } & \multicolumn{2}{|c|}{ CMV } & \multicolumn{2}{|c|}{ PVY } \\
\hline & & ELISA & Macroarray & ELISA & Macroarray & ELISA & Macroarray \\
\hline PLRV-WI & Solanum tuberosum & + & + & - & - & - & - \\
\hline PLRV\#4 & S. tuberosum & + & + & - & - & - & - \\
\hline PLRV-Sup & S. tuberosum & + & + & - & - & - & - \\
\hline PLRV-Ken & S. tuberosum & + & + & - & - & - & - \\
\hline CMV-Mal1 & Nicotiana clevelandii & - & - & + & + & - & - \\
\hline CMV-Fny & N. clevelandii & - & - & + & + & - & - \\
\hline $\mathrm{PVY}-\mathrm{Oz}$ & N. tabacum & - & - & - & - & + & + \\
\hline PVY-Mex & S. tuberosum & - & - & - & - & + & + \\
\hline PLRV+PVY-Altura & S. tuberosum & + & + & - & - & + & + \\
\hline PLRV+PVY-Buffalo & S. tuberosum & + & + & - & - & + & + \\
\hline PLRV+PVY-Cinnabar & S. tuberosum & + & + & - & - & + & + \\
\hline
\end{tabular}

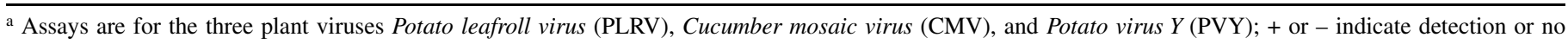
detection, respectively, in the specified assay. 
DAS-ELISA was performed on the same samples in parallel with the macroarray experiments. Results between the two techniques were entirely consistent (Table 2). In the serological assays, the optical density at $405 \mathrm{~nm}$ values for infected plant extracts ranged between 3.5 and 11 times the mean value for uninfected leaf sap.

\section{DISCUSSION}

The most significant aspect of the macroarray methodology described in this report is the potential for its use in larger arrays for the detection of all known plant viruses of a given crop group or as part of a multipathogen detection system that also can detect the presence of co-infecting bacteria, fungi, or oomycete pathogens. Although microarrays are unparalleled in their potential for the detection of huge numbers of viruses $(49,50)$ and other pathogens (53), their deployment is limited by the high costs associated with spotting and detection instrumentation, reagents, and dust-free facilities. Membrane-based macroarrays offer a significant advantage with regard to a number of constraints: no specialized instrumentation or facilities are required, materials and reagents are relatively inexpensive, probes can be easily spotted onto small pilot arrays and evaluated for effectiveness, and membranes can be reused multiple times. In these studies, membranes have been used for up to six rounds of hybridization and stripping without any apparent loss in sensitivity. DNA sequences also can be recovered from the membranes, reamplified, and sequenced (11). A remarkable example of such a recovery approach was seen with the use of a microarray in one of the original identifications of the causal agent in an outbreak of severe acute respiratory syndrome (SARS) (50). The methods described here demonstrate a viable strategy for nucleic acid amplification and hybridization that should be effective in detecting virtually any plant RNA virus for which representative sequence information is available.

We have adapted a sequence-independent amplification method originally described by Bohlander et al. (4) for the amplification of CMV, PLRV, and PVY from total RNA of infected leaves. CMV, PVY, and PLRV represent plant viruses of relatively high, medium, and low titers, and their amplification from total RNA illustrates the utility of this method to amplify plant viruses present at varying concentrations and in the presence of excess host plant RNA. Particularly encouraging is the detection of a member of the family Luteoviridae (PLRV); as phloem-restricted agents, these collectively are a benchmark for low-titer viruses (51). Because the emphasis of this report is on a description of the methodologies, a broader testing of many viral strains was not undertaken. Even with the limited number of probes (12 oligonucleotides per virus), differences were seen with the hybridization patterns among the PLRV, with each of the four single isolates yielding a unique hybridization pattern (data not shown). Thus, the technique has potential as a means of easily "fingerprinting" isolates of a virus, although mixed infections will confound interpretation.

The amplification reactions were not completely unbiased, because some specific products were amplified preferentially and visualized in stained agarose gels (Fig. 2). These products were not analyzed; however, presumably, they arose from host sequences to which the anchor primer specifically hybridized during PCR. BLAST analysis of plant sequences using the 15 or 13 nucleotides at the $3^{\prime}$ end of the anchor primer resulted in multiple hits, but not with any obvious conserved or repetitive sequences; this is consistent with the absence of any specific band that was reproducibly observed. These minor biased products did not interfere with the amplification of viral sequences and, in experiments where copy numbers were quantified, a 100- to 1,000 -fold amplification of PLRV cDNA was observed. Comparable macroarray results were obtained when amplifications were performed using either random pentamer or nonamer sequences at the $3^{\prime}$ end of the anchor primer.

During the course of $>100$ experiments, this macroarray has reproducibly provided results in agreement with those obtained using alternative diagnostic methods. Several factors proved to be critical in obtaining consistent results. Wetting the membrane in the $0.5 \% \mathrm{SDS}$ and $0.1 \mathrm{M}$ Tris- $\mathrm{HCl}$ prior to adding the prehybridization buffer eliminated variable signal and higher background. The optimized labeling and hybridization conditions employed yielded a satisfactory balance of signal and background following a 1- or 3-h exposure of the film; the background usually was excessive with overnight exposures. Accurate measurement of the concentration of the purified amplification products was crucial, because underestimation resulted in low detection signals, whereas overestimation resulted in higher background, presumably due to the higher concentrations of DNA in the hybridization buffer. The labeling reactions were performed using only $25 \%$ of the manufacturer's recommended amount of labeling reagent, providing a desired balance between cost and sensitivity.

Although the majority of the oligonucleotide probes worked as predicted, their effectiveness varied and had to be determined empirically, not on a sequence basis alone. This was exemplified by the rRNA-specific probes rRNA-1 and rRNA-5 that often yielded weak or no signals. Probe rRNA-1 was designed to hybridize to $5.8 \mathrm{~S}$ sequences and its failure may be due to the small size of the 5.8S RNA. The efficiency of random-primed reverse transcription and amplification would be expected to drop off with the size of the nucleic acid and the concomitant decrease in the number of priming positions. This has implications for the detection of pathogens with very small genomes, such as viroids or viral satellites. The probe PLRV-10 had $100 \%$ sequence identity with all database sequences for the virus, but failed to hybridize with any of the seven PLRV isolates tested. The probes PVY-9, -10, -11, and -12 consistently gave rise to relatively weak hybridization signals. These latter results might be related to the secondary structure of the viral RNAs and a resulting poor reverse transcription, amplification, or hybridization.

The sensitivity of the described macroarray was comparable with that of DAS-ELISA, with conventional RT-PCR and realtime RT-PCR being $10^{3}$ and $10^{5}$ times more sensitive, respectively. These results are consistent with other reports of RT-PCR providing $10^{2}$ to $10^{6}$ times greater sensitivity than DAS-ELISA $(29,34,40)$ and real-time RT-PCR being $10^{2}$ to $10^{4}$ times more sensitive than conventional RT-PCR $(19,32)$. It is to be expected that reports of sensitivity will vary with sources of antisera and the design and efficacy of primers. The sensitivity of the macroarray could be improved upon with an enrichment step for viral cDNAs such as subtractive hybridization. Alternatively, fluorescent labeling of the target could increase the sensitivity of the macroarray, although this would introduce a requirement for more costly instrumentation.

The emphasis of this report is methodology for the macroarray detection of RNA plant viruses using a nonradioactive label. Arrays have been developed for the detection of a number of plant pathogens. Some of the most detailed and comprehensive studies have been on the detection of oomycetes $(25,47)$. Other arrays were developed for the detection of pathogens of individual crop plants $(15,27,43)$ or, more specifically, the detection of viral pathogens $(5,7,8,24)$. Oligonucleotide hybridization patterns or fingerprints can be used to differentiate strains of plant viruses (e.g., PVY and Potato virus $S$ [8] or CMV [14]). All of these developments set the stage for the development of remarkably powerful and informative array-based multipathogen detection systems.

\section{ACKNOWLEDGMENTS}

This research was supported by U.S. Department of Agriculture NRI program grant 2004-35605-14325 to K. L. Perry. We thank C. Smart, 
N. Zhang, A. Charkowski, and J. Thompson for assistance in the development of the detection system; A. Lesvesque for protocols and advice; and L. Miller for technical support.

\section{LITERATURE CITED}

1. Abdullahi, I., Koerbler, M., Stachewicz, H., and Winter, S. 2005. The $18 \mathrm{~S}$ rDNA sequence of Synchytrium endobioticum and its utility in microarrays for the simultaneous detection of fungal and viral pathogens of potato. Appl. Microbiol. Biotechnol. 68:368-375.

2. Altschul, S. F., Madden, T. L., Schaffer, A. A., Zhang, J. H., Zhang, Z., Miller, W., and Lipman, D. J. 1997. Gapped BLAST and PSI-BLAST: A new generation of protein database search programs. Nucleic Acids Res. 25:3389-3402

3. Banik, M. T., and Zitter, T. A. 1990. Determination of cucumber mosaic virus titer in muskmelon by enzyme-linked immunosorbent assay and correlation with aphid transmission. Plant Dis. 74:857-859.

4. Bohlander, S. K., Espinosa, R., Lebeau, M. M., Rowley, J. D., and Diaz, M. O. 1992. A method for the rapid sequence-independent amplification of microdissected chromosomal material. Genomics 13:1322-1324.

5. Boonham, N., Walsh, K., Smith, P., Madagan, K., Graham, I., and Barker, I. 2003. Detection of potato viruses using microarray technology: Towards a generic method for plant viral disease diagnosis. J. Virol. Methods 108:181-187.

6. Bowtell, D., and Sambrook, J. 2003. DNA Microarrays: A Molecular Cloning Manual. Cold Spring Harbor Laboratory, Cold Spring Harbor, NY.

7. Bystricka, D., Lenz, O., Mraz, I., Dedic, P., and Sip, M. 2003. DNA microarray: Parallel detection of potato viruses. Acta Virol. 47:41-44.

8. Bystricka, D., Lenz, O., Mraz, I., Pilterova, L., Kmoch, S., and Sip, M. 2005. Oligonucleotide-based microarray: A new improvement in microarray detection of plant viruses. J. Virol. Methods 128:176-182.

9. Chizhikov, V., Wagner, M., Ivshina, A., Hoshino, Y., Kapikian, A. Z., and Chumakov, K. 2002. Detection and genotyping of human group A rotaviruses by oligonucleotide microarray hybridization. J. Clin. Microbiol. 40:2398-2407.

10. Choi, S. K., Choi, J. K., Park, W. M., and Ryu, K. H. 1999. RT-PCR detection and identification of three species of cucumoviruses with a genus-specific single pair of primers. J. Virol. Methods 83:67-73.

11. Chong, K. Y., Chen, C. M., and Choo, K. B. 1993. Post-hybridization recovery of membrane filter-bound DNA for enzymatic DNA amplification. Biotechniques 14:575.

12. Clark, A. J., and Perry, K. L. 2002. Transmissibility of field isolates of soybean viruses by Aphis glycines. Plant Dis. 86:1219-1222.

13. Culley, A. I., Lang, A. S., and Suttle, C. A. 2003. High diversity of unknown picorna-like viruses in the sea. Nature 424:1054-1057.

14. Deyong, Z., Willingmann, P., Heinze, C., Adam, G., Pfunder, M., Frey, B., and Frey, J. E. 2005. Differentiation of cucumber mosaic virus isolates by hybridization to oligonucleotides in a microarray format. J. Virol. Methods 123:101-108.

15. Fessehaie, A., De Boer, S. H., and Levesque, C. A. 2003. An oligonucleotide array for the identification and differentiation of bacteria pathogenic on potato. Phytopathology 93:262-269.

16. Fitzgibbon, J. E., and Sagripanti, J. L. 2006. Simultaneous identification of orthopoxviruses and alphaviruses by oligonucleotide macroarray with special emphasis on detection of variola and Venezuelan equine encephalitis viruses. J. Virol. Methods 131:160-167.

17. Gibbs, A., and Mackenzie, A. 1997. A primer pair for amplifying part of the genome of all potyvirids by RT-PCR. J. Virol. Methods 63:9-16.

18. Ginocchio, C. C., Zhang, F., Malhotra, A., Manji, R., Sillekens, P., Foolen, H., Overdyk, M., and Peeters, M. 2005. Development, technical performance, and clinical evaluation of a NucliSens basic kit application for detection of enterovirus RNA in cerebrospinal fluid. J. Clin. Microbiol. 43:2616-2623.

19. Harju, V. A., Skelton, A., Clover, G. R. G., Ratti, C., Boonham, N., Henry, C. M., and Mumford, R. A. 2005. The use of real-time RT-PCR (TaqMan) and post-ELISA virus release for the detection of Beet necrotic yellow vein virus types containing RNA 5 and its comparison with conventional RT-PCR. J. Virol. Methods 123:73-80.

20. Kawasaki, E., Saiki, R., and Erlich, H. 1993. Genetic analysis using polymerase chain reaction-amplified DNA and immobilized oligonucleotide probes: Reverse dot-blot typing. Methods Enzymol. 218:369381.

21. Klaassen, C. H. W., Prinsen, C. F. M., de Valk, H. A., Horrevorts, A. M., Jeunink, M. A. F., and Thunnissen, F. 2004. DNA microarray format for detection and subtyping of human papillomavirus. J. Clin. Microbiol. 42:2152-2160

22. Kozal, M. J., Shah, N., Shen, N. P., Yang, R., Fucini, R., Merigan, T. C., Richman, D. D., Morris, D., Hubbell, E. R., Chee, M., and Gingeras, T. R.
1996. Extensive polymorphisms observed in HIV-1 clade B protease gene using high-density oligonucleotide arrays. Nat. Med. 2:753-759.

23. Lapa, S., Mikheev, M., Shchelkunov, S., Mikhailovich, V., Sobolev, A., Blinov, V., Babkin, I., Guskov, A., Sokunova, E., Zasedatelev, A., Sandakhchiev, L., and Mirzabekov, A. 2002. Species-level identification of orthopoxviruses with an oligonucleotide microchip. J. Clin. Microbiol. 40:753-757.

24. Lee, G. P., Min, B. E., Kim, C. S., Choi, S. H., Harn, C. H., Kim, S. U., and Ryu, K. H. 2003. Plant virus cDNA chip hybridization for detection and differentiation of four cucurbit-infecting Tobamoviruses. J. Virol. Methods 110:19.

25. Levesque, C. A., Harlton, C. E., and de Cock, A. W. A. M. 1998. Identification of some oomycetes by reverse dot blot hybridization. Phytopathology 88:213-222.

26. Li, J., Chen, S., and Evans, D. H. 2001. Typing and subtyping influenza virus using DNA microarrays and multiplex reverse transcriptase PCR. J. Clin. Microbiol. 39:696-704.

27. Lievens, B., Brouwer, M., Vanachter, A., Levesque, C. A., Cammue, B. P. A., and Thomma, B. 2003. Design and development of a DNA array for rapid detection and identification of multiple tomato vascular wilt pathogens. FEMS Microbiol. Lett. 223:113-122.

28. Lin, B. C., Vora, G. J., Thach, D., Walter, E., Metzgar, D., Tibbetts, C., and Stenger, D. A. 2004. Use of oligonucleotide microarrays for rapid detection and serotyping of acute respiratory disease-associated adenoviruses. J. Clin. Microbiol. 42:3232-3239.

29. Lunello, P., Mansilla, C., Conci, V., and Ponz, F. 2004. Ultra-sensitive detection of two garlic potyviruses using a real-time fluorescent (Taq$\operatorname{man}(\mathrm{R}))$ RT-PCR assay. J. Virol. Methods 118:15.

30. Martin, R. R., James, D., and Levesque, C. A. 2000. Impacts of molecular diagnostic technologies on plant disease management. Annu. Rev. Phytopathol. 38:207-239.

31. Ng, J., and Perry, K. L. 1999. Stability of the aphid transmission phenotype in cucumber mosaic virus. Plant Pathol. 48:388-394.

32. Olmos, A., Bertolini, E., Gil, M., and Cambra, M. 2005. Real-time assay for quantitative detection of non-persistently transmitted Plum pox virus RNA targets in single aphids. J. Virol. Methods 128:151-155.

33. Owen, J., Shintaku, M., Aeschleman, P., Tahar, S. B., and Palukaitis, P. 1990. Nucleotide sequence and evolutionary relationships of cucumber mosaic virus (CMV) strains: CMV RNA 3. J. Gen. Virol. 71:2243-2249.

34. Ratti, C., Budge, G., Ward, L., Clover, G., Rubies-Autonell, C., and Henry, C. 2004. Detection and relative quantitation of Soil-borne cereal mosaic virus (SBCMV) and Polymyxa graminis in winter wheat using real-time PCR (TaqMan). J. Virol. Methods 122:95-103.

35. Rizzo, T. M., and Palukaitis, P. 1988. Nucleotide-sequence and evolutionary relationships of cucumber mosaic virus (CMV) strains: CMV RNA 2. J. Gen. Virol. 69:1777-1787.

36. Rizzo, T. M., and Palukaitis, P. 1989. Nucleotide-sequence and evolutionary relationships of Cucumber mosaic virus (CMV) strains: CMV RNA 1. J. Gen. Virol. 70:1-11.

37. Robertson, N. L., French, R., and Gray, S. M. 1991. Use of group-specific primers and the polymerase chain-reaction for the detection and identification of luteoviruses. J. Gen. Virol. 72:1473-1477.

38. Saldarelli, P., Rowhani, A., Routh, G., Minafra, A., and Digiaro, M. 1998. Use of degenerate primers in a RT-PCR assay for the identification and analysis of some filamentous viruses, with special reference to closteroand vitiviruses of the grapevine. Eur. J. Plant Pathol. 104:945-950.

39. Sambrook, J., Fritsch, E. F., and Maniatis, T. 1989. Molecular Cloning: A Laboratory Manual. 2nd ed. Cold Spring Harbor Laboratory, Cold Spring Harbor, NY.

40. Sanchez-Navarro, J. A., Aparicio, F., Rowhani, A., and Pallas, V. 1998. Comparative analysis of ELISA, nonradioactive molecular hybridization and PCR for the detection of Prunus necrotic ringspot virus in herbaceous and Prunus hosts. Plant Pathol. 47:780-786.

41. Sanchez-Seco, M. P., Echevarria, J. M., Hernandez, L., Estevez, D., Navarro-Mari, J. M., and Tenorio, A. 2003. Detection and identification of Toscana and other phleboviruses by RT-nested-PCR assays with degenerated primers. J. Med. Virol. 71:140-149.

42. Shih, S. R., Wang, Y. W., Chen, G. W., Chang, L. Y., Lin, T. Y., Tseng, M. C., Chiang, C., Tsao, K. C., Huang, C. G., Shio, M. R., Tai, J. H., Wang, S. H., Kuo, R. L., and Liu, W. T. 2003. Serotype-specific detection of enterovirus 71 in clinical specimens by DNA microchip array. J. Virol. Methods 111:55-60.

43. Sholberg, P., O'Gorman, D., Bedford, K., and Levesque, C. A. 2005. Development of a DNA macroarray for detection and monitoring of economically important apple diseases. Plant Dis. 89:1143-1150.

44. Singh, M., and Singh, R. P. 1996. Nucleotide sequence and genome organization of a Canadian isolate of the common strain of potato virus $Y$ (PVYO). Can. J. Plant Pathol. 18:209-224.

45. Slack, S. A. 1993. Seed certification and seed improvement programs. Pages 61-65 in: Potato Health Management. R. C. Rowe, ed. The 
American Phytopathological Society, St. Paul, MN.

46. Slack, S. A., and Tufford, L. A. 1995. Meristem culture for virus elimination. Pages 117-128 in: Fundamental Methods of Plant Cell, Tissue and Organ Culture and Laboratory Operations. O. L. Gamborg and G. C. Phillips, eds. Springer-Velag, Berlin.

47. Tambong, J. T., de Cock, A., Tinker, N. A., and Levesque, C. A. 2006. Oligonucleotide array for identification and detection of Pythium species. Appl. Environ. Microbiol. 72:2691-2706.

48. Tzanetakis, I. E., Keller, K. E., and Martin, R. R. 2005. The use of reverse transcriptase for efficient first- and second-strand cDNA synthesis from single- and double-stranded RNA templates. J. Virol. Methods 124:73-77.

49. Wang, D., Coscoy, L., Zylberberg, M., Avila, P. C., Boushey, H. A., Ganem, D., and DeRisi, J. L. 2002. Microarray-based detection and genotyping of viral pathogens. Proc. Natl. Acad. Sci. USA 99:15687-15692.
50. Wang, D., Urisman, A., Liu, Y. T., Springer, M., Ksiazek, T. G., Erdman, D. D., Mardis, E. R., Hickenbotham, M., Magrini, V., Eldred, J., Latreille, J. P., Wilson, R. K., Ganem, D., and DeRisi, J. L. 2003. Viral discovery and sequence recovery using DNA microarrays. PLoS Biol. 1:257-260.

51. Waterhouse, P. M., Gildow, F. E., and Johnstone, G. R. 1988. Luteoviridae. Pages Number 399 in: CMI/AAB Descriptions of Plant Viruses. B. D. Harrison and A. F. Murant, eds. Commonwealth Agricultural Bureau/Association of Applied Biologists, Kew, U.K.

52. Webster, C. G., Wylie, S. J., and Jones, M. G. K. 2004. Diagnosis of plant viral pathogens. Curr. Sci. 86:1604-1607.

53. Wilson, W. J., Strout, C. L., DeSantis, T. Z., Stilwell, J. L., Carrano, A. V., and Andersen, G. L. 2002. Sequence-specific identification of 18 pathogenic microorganisms using microarray technology. Mol. Cell. Probes 16:119-127. 